This is the penultimate draft of a chapter that is forthcoming in the The Routledge Handbook of Dehumanization, ed. by Maria Kronfeldner, London/New York: Routledge.

https://www.routledge.com/The-Routledge-Handbook-of-Dehumanization/Kronfeldner/p/book/9781138588158

\title{
Dehumanizing Strategies in Nazi Ideology and their Anthropological Context
} Johannes Steizinger

\section{Abstract}

This chapter explores the ideological dimension of dehumanization in the context of National Socialism, focusing on the connection between concepts of humanity and dehumanizing images. NS regarded itself as a political revolution, realizing a new concept of humanity. Nazi ideologues undergirded the self-understanding of NS by developing racist anthropologies. I examine two major strands of Nazi ideology, focusing on their diverging strategies of dehumanization, and arguing that they were dependent on different anthropological frameworks. Richard Walther Darré held a naturalistic concept of humanity and advanced biologistic forms of dehumanization. Alfred Rosenberg developed a dualistic anthropology that combined metaphysical and natural features. He dehumanized certain groups of people by reducing them to being human in a natural sense only.

Moreover, I aim to show that the key motifs of these racist worldviews were prevalent in the scientific and philosophical debates on anthropology in early-twentieth-century Germany. I thus explore the general orientation of both the naturalistic and the anti-naturalistic strand in anthropological thought, unfold the animalizing tendencies of these views, and emphasize their 
conformity with the key motifs of Nazi ideology. The case of NS should thus exemplify the dehumanizing potential of anthropological theories.

\section{Introduction}

Dehumanization is often discussed as a psychological phenomenon that occurs in contexts of mass violence. Many scholars use National Socialism (NS) as their prime example of the significance of psychological dehumanization for campaigns of mass murder. This debate focuses on the causal question whether dehumanization is a necessary prerequisite of the participation of ordinary people in atrocities like the Shoah. Some authors argue that the moral inhibition against murdering fellow humans is so strong that all social and emotional bonds with the victims have to be erased in order to execute mass killings (see e.g. Kelman 1973; Volpato and Contarello 1999; Smith 2011, 2016). Others question whether psychological dehumanization is a necessary condition for mass violence (see e.g. Kuper 1981; Brudholm 2010; Lang 2010, 2017; Weissmann 2015). Lang (2010, 2017) emphasizes the psychological meaning of violence and cruelty for the social identity of perpetrators. His detailed account of the excessive violence in Concentrations Camps focuses on the social interactions between perpetrators and victims that presuppose the acknowledgment of the victim's subjectivity and, hence, humanness. I will return to Lang's critique of dehumanization in the conclusion. This debate has long suffered from the one-sided emphasis on psychological accounts of dehumanization. The ideological and political embeddedness of social situations which involve psychological dehumanization, has only recently received more attention (see e.g. Fiske and Rai 
2014; Confino 2014; Steizinger 2018). I follow this turn to the role of ideology for understanding dehumanization in contexts of mass violence. My analysis focuses on the dehumanizing strategies that characterize Nazi ideology.

NS regarded itself as a political revolution, realizing a new concept of humanity. Nazi ideologues undergirded the self-understanding of NS by developing racist anthropologies, advancing dehumanizing images of certain groups of people. ${ }^{i}$ The devaluation of these groups often was expressed by identifying them with animal life forms. Images like the "Jewish parasite" and the murderous policy that this "enemy" of the German people demands were an essential part of the perpetual flow of propaganda in daily life. I argue that Nazi ideologues developed different justifications of the racist core of NS, and that their strategies of dehumanization depended on their varying concepts of humanity. Moreover, I aim to show that the key motifs of these racist worldviews were prevalent in the scientific and philosophical debates on anthropology in earlytwentieth-century Germany. My analysis thus focuses on the connection between concepts of humanity and dehumanizing images, demonstrating the dehumanizing potential of different anthropological theories.

My argument involves four steps: Section 2 starts with an analysis of the general character and the basic assumptions of Nazi ideology. Then, I turn to two major strands of Nazi ideology, concentrating on the views of two ideologues that belonged to the inner circle of the NSDAP. Section 3 examines Richard Walther Darré's naturalistic concept of humanity and his biologistic strategies of animalistic dehumanization. Darré developed his racist worldview, which centered 
on the slogan of "blood and soil," in the völkisch circles of the 1920s, joining the NSDAP and the SS in 1930. He was head of the SS Race and Settlement Main Office from 1932 to 1938 and was appointed Reich Minister of Food and Agriculture in June 1933 (for a detailed account of Darré's life and thought see Gies 2019). Section 4 analyses Alfred Rosenberg's dualistic anthropology and focuses on how his metaphysical understanding of the essence of humanity shaped his image of the "Jewish parasite," invoking one of the most vicious forms of animalistic dehumanization. A member of the NSDAP since 1919, Rosenberg shaped its ideology by his writings and by his administrative work as editor-in-chief (Hauptschriftleiter) of the party's newspaper Völkischer Beobachter (Völkisch Observer). He also belonged to the political leadership of the NSDAP after the Nazi seizure of power, being responsible for the spiritual and philosophical education of members of the party and all related organizations as head of the socalled Amt Rosenberg (Rosenberg office). Section 5 turns to the scientific and philosophical debates on anthropology in early-twentieth-century Germany, exploring the general orientation of both the naturalistic and the anti-naturalistic strand in anthropological thought, unfolding the animalizing tendencies of these views, and highlighting their conformity with the key motifs of Nazi ideology.

In focusing on ideology, I circumvent one of the main issues that has been justifiably raised against psychological approaches who use dehumanization as a causal explanation for the emergence of mass violence.i Psychological accounts are often criticised for their anthropological anachronism. Lang (2010: 230, 2017: 193 f., 198) has criticized psychologists who characterize the treatment of concentration camp inmates as dehumanizing for applying 
their own concept of humanity to this context, arguing that such interpretations tell us more about the mindset of the commentator than about the psychology of the perpetrators. Any understanding of dehumanization should, rather, proceed from a clear sense of what is being denied to the other, i.e. humanness. The focus on ideology makes it possible to critically analyze the concepts of humanity that were developed by Nazi ideologues themselves and that grounded their dehumanizing images of other people. Considering the ideological dimension of dehumanization thus avoids the anthropological anachronism of many psychological approaches which apply current or idealized concepts of humanity to the historical context.

\section{The Significance and Character of Nazi Ideology}

Recent historical research shows the significance of ideology for the broad success of the Nazi movement, including the establishment of its political power and the continuing execution of its policies. Detailed accounts of the basic convictions of party leaders like Hitler, Himmler, Goebbels or Rosenberg reveal rather comprehensive, more or less consistent, yet divergent doctrines which guided the political decision-making and were part of the well-known power struggles within the inner circle of the NSDAP (e.g., Kroll 1998, Bärsch 2002). Such nuanced examinations of the ideological dimension of NS suggest a new understanding of its structure. Nazi ideology has to be seen as set of basic beliefs and convictions which offered much scope for interpretation. Although key concepts like race had to be accepted as guidelines of thinking and acting, different interpretations of such ideological core elements coexisted and competed even in the inner circle of Nazi leadership. While demanding a general appeal and specific 
direction, the Nazi worldview remained open to individual and contextualized interpretations (see Raphael 2014). Take the example of the concept of race: once you had accepted its key role for understanding whatever phenomenon interests you, you could engage in the heated debate on its meaning and significance (see Koonz 2003: 190-220; Hutton 2005). The range which was developed in the ideological writings of political leaders varied from bluntly biological conceptions (e.g. Darré) to metaphysical interpretations of race (e.g. Rosenberg). Such obvious tensions were never removed and created the impression that NS was always in need for further explication.

The realization of a new human was a key message of Nazi politics. This political vision was rooted in some basic assumptions about humanity that were shared by most Nazi ideologues. They carved up humanity into different racial types, believing that race was an essential property of humans that structured the world. Nazi ideologues regarded the struggle of races as the ultimate cause behind the course of history. The racial types had to be realized in history by "fighting" ("Kampf") and "breeding" ("Zucht"), whereby Völker were their historical manifestation (though the distinction between race and Volk was highly controversial and remained notoriously unclear; see Hutton 2005). The "racial purity" of a Volk was defined as both a comprehensive ideal and an existential necessity: "racial mixture" was tantamount to decline of community and led to the vanishing of a specific type. Hence, a Volk had to assert itself against all forms of otherness to become and remain the type it was: it had to be itself biologically as well as culturally, physically, as well as intellectually, inwardly as well as outwardly. The distinction between Völker came in degrees: communities from the same racial 
type were akin to each other and may understand each other on a basic level. Yet some races were totally alien to each other and hence lacked any mutual understanding, making them natural enemies.

Nazi ideologues presented their racial particularism as the anthropological alternative to universalistic concepts of humanity, attacking quite different views such as Judaism, Catholicism, Liberalism, Marxism, or humanism for their universalistic outlook. They argued that universalist doctrines provided only abstract accounts of human life which did not capture its actual reality. They concluded that such approaches were false and, moreover, often suggested that all universal concepts of humanity were deceitful fictions. From a Nazi perspective, universalists suggested that a certain way of life was the only way of life, thus threatening the identity of all other people. Here, identity meant collective identity and the latter was constituted by belonging to a particular community. Many Nazi ideologues held that in the wake of modernity, many people, in adapting to Western culture, lost their particular identity, and that universalist doctrines hid this fact.

The Nazis believed that racial differences revealed a deep inequality between humans, making racism a core element of their ideology. They ranked races according to their alleged cultural achievements, advancing a supposedly objective hierarchy of races and rejection all kinds of egalitarianism. The "Nordic race" was usually defined as the "master race" (Herrenrasse), representing the essence of humanity. Many Nazi ideologues claimed that the Nordic race was the only race who possessed the creative strength to develop culture. On this view, all cultural 
forms including morality, states, science, or metaphysics were defined as Nordic achievements. Hence, only Nordic communities fulfilled the full potential of humanity. Yet there were different explanations for why the Nordic race was inclined toward developing culture, some assuming biological dispositions (e.g. Darré), others social (e.g. Hitler), or even metaphysical dispositions

(e.g. Rosenberg). Other groups of people, especially Jews, were often characterized as completely without the capacity for culture and thus full humanness. Nazi ideology was meant to justify the degradation of certain groups of people to something less than fully human. In the following, I analyze these ideological strategies of dehumanization, arguing that they rested on the Nazi concepts of humanity. I consider two main strands of Nazi ideology, first considering Darré's biologistic understanding of race, then turning to Rosenberg's metaphysics of race. After having presented the commonalties between these versions of Nazi ideology so far, I will focus on their differences in the following.

\section{Biological Racism: Darré's Animalization of Humanity}

Some Nazi ideologues regarded race as a strictly biological concept and advocated a complete naturalisation of the human sphere. Darré held such a biologistic view, claiming that humans are, like animals, part of the natural world and thus completely subjected to the laws of nature. He defined races as natural groups who provide the genetic make-up of its members and whose characteristics had to be studied by scientific methods. Darré believed in the priority of physiological traits, holding that bodily features also determine the intellectual capacities of an individual (Darré 1937: 136-140, 1942: 437-440). Here, Nazi anthropology was tantamount to a 
simple form of naturalism that regarded humans, first and foremost, as animals. Darré drew many analogies between humans and animals, often explaining human characteristics by a comparison with similar phenomena in the animal world (Darré 1942: 248 f., 1937: 52, 435 ff.). These comparisons were often meant in a literal sense. Darré explicitly claimed that early humans and closely related primates developed similar forms of social life: they shared nutritional habits, organized their reproductive life in monogamous relationships and large families, and developed an aggressive attitude to other groups as consequence of their form of life (Darre 1942: 222, 225, 232 ff.). He even extended the parallels between humans and animals to the realm of culture, identifying the cultivation of human life with the domestication of animals, claiming that both resulted from the same processes of breeding.

From such a perspective, the social world, cultural achievements, and political claims were explained and justified by biological concepts. Darré explicitly called for the recognition and acceptance of the biological laws that shaped humanity, and for pursuing all human affairs in accordance with them. He advanced a social Darwinist position, emphasizing the significance of the general laws of reproduction and heredity for human development, and demanding that the natural mechanisms of selection undergirded social institutions. For Darré, the preservation of racial types was the key purpose in human history. This task could only be fulfilled, when a Volk bred a nobility (Adel) that represented the "outstanding elements" of its race, and eradicated the "inferior elements" ruthlessly (Darré 1937: 52, 159). Darré understood the selective breeding of humans in terms of animal breeding, claiming time and again that the law of "pure blood" was first discovered by animal breeders whose experience should guide the application 
of biological principles to the social world (Darré 1942: 275 f., 358 ff., 365 ff., 435 ff.). He also claimed that there had been Völker such as the Germanics or the Spartans who had followed the "iron law" of the "proven blood" ("bewährtes Blut") intuitively (Darré 1942: 364 f., 440 ff.).

Darré believed in a biological foundation of racial differences, arguing that the inequality of races was caused by varying natural capacities. He saw humanity characterized by the natural antagonism between the "Nordic settler-race" (Nordische Siedlerrasse) and the "nomadic wander-race" (nomadische Wanderrasse). Of course, Darré defined the Nordic race as the most gifted race, attributing a special way of life to its members, namely farming. He assumed that the life of farmers was rooted in a certain attitude to the world: they were bound to their land, understood the organic laws of life, and developed a consciousness of the world that enabled them to form their environment. Only Nordic communities were thus gifted with the creative strength to develop culture, and could live in a truly human way. Darré emphasized the reliability, altruism, and heroism of Nordic people, characterizing their life as the source of morality and personality (Darré 1937: 62 f., 1942, 32 f., 295 ff., 336 f). The "wander-race", on the other hand, was defined as the opposite of Nordic humanity, lacking its natural capacities. For Darré, the "wander-race" included different people such as the Jews, the Arabs, the Huns, the Tatars, or the Native Americans. He claimed that nomadic people could only "exploit and graze" what nature gave or what others achieved, making them literally "parasites," destroying their environment and robbing other people, leaving behind dead deserts (Darré 1942: 50; also $40 \mathrm{ff} ., 295 \mathrm{ff})$. He depicted nomads as uprooted, cowardly, and immoral egoists without personality and inclined to "bestial cruelty" (Darré 1942: 40-42), explicitly defining them as 
"subhumanity" (Untermenschentum) that threatens the cultural achievements of the Nordic race (Darré 1937: 51 f., 132, 1940a: 71 ff., 1940b: 118-134, 126 f.). Hence, Darré believed in a separation within humanity itself, putting the Nordic farmers with their distinctively human way of life on the one side, and the bestial nomads of the wander-race on the other side. He regarded human history as the existential clash between these two kinds of life, Nordic humanity on the hand, and nomadic subhumanity on the other hand.

Darré's biologistic anthropology was characterized by two kinds of dehumanization. First, Darré naturalized humanity in general, thus including humans in the animal world and regarding them, first and foremost, as human animals. He believed that all characteristics of human life were rooted in natural dispositions and could be explained by the same laws that governed animal life, animalizing humans and their social forms in a literal sense. Darré thus dehumanized humanity in general. Second, he claimed that certain groups of people were gifted with exceptional natural capacities, enabling them to develop distinctively human features such as culture, morality, or personality, making their way of life truly human. Other groups of people were dehumanized insofar as their life lacked the specifically human characteristics, degrading them to bestial subhumans only. This dehumanizing mechanism rested on a separation within humanity itself that was understood as an evolutionary gap - a widespread conviction among Nazi thinkers (e.g. Gauch 1933). Darré characterized the bestial subhumans as the exact opposite of true humanness, determining the latter as a certain way of life based on biological dispositions. Both kinds of dehumanization were thus undergirded by the naturalistic framework of his racist anthropology. 


\section{Metaphysical Racism: Rosenberg's Image of the "Jewish Parasite"}

Although the naturalization of the humanity was an important feature of Nazi anthropology, several Nazi ideologues still rejected biologism. Rosenberg was a striking example of this tendency in Nazi ideology. He explicitly claimed that the concept of race was not merely biological, developing a dualistic anthropology which combined natural and metaphysical features. According to Rosenberg, the property of race was tantamount to the essence of humans that distinguished them fundamentally from the animal world. He used the term "racesoul" to signify the deep, spiritual unity of human groups that could not be found in nature. Rosenberg held that "each race has its soul, each soul its race," (Rosenberg 1971: 83 [1938: 116]) placing the essence of humanity in the spiritual realm. ${ }^{\text {iii }}$ For Rosenberg, only humans, but not all humans possessed a "race-soul," enabling them to develop a collective identity which is expressed in the distinctive culture of a community.

The naturalization of humanity was nevertheless an important motif in Rosenberg's racist anthropology: Human groups without a "race-soul" were portrayed as mere human animals whose life lacked any metaphysical and cultural dimension. The image of the "Jewish parasite" was the ultimate expression of this dehumanizing animalization of certain groups of people. Here, the combination of natural and metaphysical features in the concept of humanity grounded the dehumanizing mechanism. The naturalistic dimension of metaphysical anthropology, on the one hand, explains why humans could be animalized in a literal sense. For 
instance, Rosenberg claimed that his characterization of the Jews as parasites has to been seen as a description of a biological fact (Rosenberg 1938: 461). Such a conviction is only possible if humanity is seen as part of the natural world and if biological concepts can be used to explain social relationships. The metaphysical dimension, on the other hand, explains why animalization could be used as a form of dehumanization. In the metaphysical version of Nazi anthropology, natural features were not enough to be considered as fully human. Rosenberg regarded a specific disposition as the essence of humanity: the capacity to develop a collective identity which was restricted to certain groups of people.

In the following, I analyze this complex strategy of dehumanization, focusing on Rosenberg's main work Mythus des 20. Jahrhunderts (Myth of the $20^{\text {th }}$ Century). First, I examine the metaphysical aspect of his anthropology that shapes his characterization of full humanness (a), then turning to the animalization of the Jews $(b){ }^{. i v}$

a) "Nordic" Humanity: Rosenberg developed a metaphysical understanding of race, claiming that the unique inner and outer character of a race was shaped by a "spiritual center." This "essential unity" of a race was expressed in its myth and thus remembering that myth enabled a community to develop self-consciousness, i.e. to become the Volk it is (Rosenberg 1971: $97 \mathrm{f}$. $[1938,698])$. This self-realization of a community was guided by a specific "highest value" (Höchstwert; see Rosenberg 1938: 116 f. [my translation]). Each race developed a different core value that was passed on by its myth and had to be recognized. The evaluative centre of a race was expressed in the moral, political, and religious systems of its communities, making the 
establishment of a type-appropriate (artgerechte) culture an essential part of the selfrealization of a community. Rosenberg was convinced that only one race, the Nordic race of course, was capable of developing "Volkish personalities" (völkische Persönlichkeiten; Rosenberg 1971: 116 [1938: 249]). These Nordic communities shared the same highest value, namely the concepts of honor and duty. These "spiritual essences" of the Nordic race enabled its members to create particular communities. Rosenberg depicted the Vikings as an example of a community that was solely shaped by its own intrinsic values and thus constituted a complete unity (Rosenberg 1971: 102 f. [1938: 152]). Here, selfhood became the most important criterion to assess the value of a community: the more a community knows, realizes and expresses itself, the better, and the degree of this indicates how human the community is.

Rosenberg regarded this particularist disposition as a prerequisite of cultural development and hence of full humanness. He believed that only the Nordic race possessed the creative strength to develop culture. Again, culture was the distinctive feature of the superior race and its humanness. Rosenberg held that, today, only the Germans were capable of the deliberate particularism that was essential for being fully human. While the Germans had to fight for their place at the top of the racial hierarchy, other groups of people were characterized as completely without the capacity for identity, culture, and thus full humanness.

b) The Image of the "Jewish parasite": The racist characterization of other groups of people rested on the naturalistic dimension of Nazi anthropology. Rosenberg's anti-Semitism was an example of the conviction that there were humans who did not possess the essence of 
humanity and thus were mere human animals. He emphasized time and again the "uncreative character" of Jews, contrasting their properties to what he regarded as uniquely human. Jews were, according to Rosenberg, "copycats" (Nachäffer), "plagiarizers," and "nihilists" who possessed "no talent for indigenous growth, no organic shape of the soul and therefore no racial shape" (Rosenberg 1938, 461 [my translation]). Thus, he defined the Jews as an "antirace" (Gegenrasse) whose members lacked what it means to be fully human: collective identity. Moreover, he claimed that Jewish life is without any metaphysical or cultural dimension and is hence animal-like. This dehumanizing naturalization of the Jew was a major motif of the Mythus. Rosenberg claimed that the "Jewish relationship to the world" was only guided by "instinct" and that Jews were always driven by selfish, material, superficial, and libidinous interests (Rosenberg 1938: 263 f., 272, 363 f., 460). He suggested that this disposition caused a completely inhuman behavior, giving one absurd example after the other of alleged Jewish cruelties in history (Rosenberg 1938: 123 f., 455 f., 459-466). For Rosenberg, Jews essentially were nothing but human animals that advanced a "parasitical devaluation" and "bestial materialization" of the human world (Rosenberg 1938: 265 f., 460 [my translation]). He left no doubt that his dehumanization of Jews was literally meant as an animalization, insisting on the literal meaning of his characterization of Jews as parasites:

"In this context the concept [of parasitism] will not be grasped as a moral evaluation but as the characterisation of a biological fact, in exactly the same way as we speak of parasitical phenomena in the plant and animal world. The sack crab bores through the posterior of the pocket crab, gradually growing into the latter, sucking out its last life strength. This is an 
identical process to that in which the Jew penetrates into society through the open wounds in the body of the people, feeding off their racial and creative strength until their decline." (Rosenberg 1938: 461 [my translation]).

The image of the "Jewish parasite" was a prime example of the animalistic dehumanization that also shaped the Nazi concept of the enemy. According to Rosenberg, Nordic communities sought to develop and sustain their particular identity. Thus, these "Volkish personalities" concentrated, first and foremost, on themselves. All subhuman groups of people and especially the Jews lacked this ability and hence had to spread for survival: they were "eternal wanderers" without a homeland and dependent on their host societies whom they "suck dry." this "expansive" and "destructive" form of life, the Jews were defined as a permanent threat to the particular communities of the Nordic race and thus to all cultural forms of human life (Rosenberg 1938: 671 [my translation]). Rosenberg explicitly claimed that the Jews were a threat to humanity in itself and emphasized that "we are face to face with a final decision today" (Rosenberg 1938: 82 [my translation]).

Rosenberg's metaphysics of race is an extreme example of the non-biologistic version of Nazi racism that advanced a specific separation within humanity itself. Rosenberg regarded culture as the manifestation of the essential property that separated humans from animals and mere human animals. Similar views can also be found in less metaphysical approaches. In the chapter Volk und Rasse ("Volk and Race") of Mein Kampf ("My Struggle"), Hitler contrasted the social attitude of humans to the natural egoism of animals, claiming that humans were characterized 
by a sense of community that transcended the instinct of self-preservation. Hitler held that all culture depended on this social disposition (Gesinnung) that demanded the sacrifice of the individual for the sake of the community ${ }^{\text {vi }}$ According to him, only this "true idealism" created the "concept of human" (Hitler 1925: 316 [my translation]). The heroism of a community thus showed the humanness of the race it belonged to. The Aryans and its people were, of course, at the top of this ranking. They founded and preserved, according to Hitler, human culture (Hitler 1925: 311-312). However, there were also races which were not capable of being human in the full sense. Hitler claimed that the Jews possessed no "idealistic disposition" (idealistische Gesinnung): Since they were only driven by the instinct of self-preservation, they basically remained animals (Hitler 1925: 317-320 [my translation]). At this point it should be obvious that Hitler put forward a strategy of dehumanization similar to Rosenberg's. We can therefore justifiably say that Nazi racism could be based on a dualistic anthropology that combined biological and metaphysical perspectives.

The examination of two strands of Nazi anthropology demonstrates that different concepts of humanity gave rise to diverging, yet interconnected strategies of dehumanization. The naturalistic anthropology of Darré denied any fundamental distinction between humans and animals, thus animalizing humanity in general. He argued that all human affairs could be explained by the natural mechanisms that governed animal life as well. In addition, Darré believed in an evolutionary gap within humanity itself, claiming that only certain groups of people possessed the natural capacities to become truly human. Other groups were dehumanized insofar as their life lacked the specifically human characteristics such as culture, 
morality, or personality, degrading them to bestial subhumans only. Although Darré's understanding of true humanness referred to cultural features, he insisted on their biological foundation, thus developing an extreme natural hierarchy of human groups. Both kinds of dehumanization were supported by the naturalistic framework of Darré's anthropology.

The idea of a separation within humanity proved to be the key motif of the metaphysical strand in Nazi anthropology that was developed by Rosenberg in particular. His dualistic anthropology emphasized a dividing line between being human in a naturalistic sense, on the one hand, and being human in the metaphysical sense, on the other hand, creating a fundamental distinction: Only some groups of people met the metaphysical criterion of being human. Members of these groups were considered as essentially and hence fully human, while other groups of people were reduced to the biological sense of being human. They simply lacked the metaphysical essence of humanity and thus were characterized as mere human animals. These creatures were human only from the naturalistic point of view, but not human from a metaphysical point of view, making them subhumans who were not fully human, but also not completely nonhuman. For Rosenberg, humans constituted a specific species within the animal sphere. Hence, human animals were also different from non-human animals.

\section{The Intellectual Context: Anthropology in Early Twentieth Century Germany}

Recent research has demonstrated that Nazi ideology was well embedded in the intellectual contexts of the early twentieth century, revealing the complex relationship between academic 
and ideological discourses before and after 1933. The multi-layered contributions of biological anthropology and racial science to the racist core of the Nazi worldview and the policies of the Nazi regime are well researched (see e.g. Weingart, Bayertz and Kroll 1992; Weikart 2004; Weiss 2010). Some authors have emphasized the ambivalences of Nazi ideology and have focused on the influence of the anti-scientific discourses that flourished in the philosophical context of the early twentieth century (see e.g. Sluga 1993; Harrington 1996; Varshizky 2017a, 2017b). vii In the following, I will neither revisit the complex role of academic discourses on race for the ideological and political formation of NS, nor examine the involvement of certain scientists and scholars in Nazi ideology and politics. I rather aim to show that the motifs that ground the dehumanizing strategies of Nazi ideology were key issues in the anthropological debates in early-twentieth-century Germany. Nazi ideologues could thus draw on widely accepted motifs from the competing strands of contemporary anthropology to justify their racist views. In tracing these conceptual contexts, I seek to support my thesis that the dehumanizing images were rooted in specific concepts of humanity.

My analysis considers two main strands of anthropological thought in early-twentieth-century Germany: First, I sketch the establishment of biological anthropology after Darwin, concentrating on the Darwinian reformulation of racial anthropology in the volume Menschliche Erblichkeitslehre (trans. as Human Hereditary Teaching and Racial Hygiene) that was coauthored by the racial scientists Erwin Baur, Eugen Fischer, and Frith Lenz (a). viii Second, I turn to the philosophical approaches that rejected naturalism, focusing on the dualistic framework of Scheler's metaphysical anthropology (b). Note that I do not intend to examine to what extent 
these scientific and philosophical anthropologies were actual predecessors of Nazi ideology. I thus do not evaluate the concrete contributions of these scientists and philosophers to Nazi ideology and politics. My analysis focuses completely on the structural similarities between the ideological and the scholarly concepts of humanity as well as their dehumanizing potential.

a) Biological Anthropology: Charles Darwin's theory of natural selection provided a new conceptual framework within which to understand the place of human beings within nature, and the forces that act upon them. In his Descent of Man (1871), Darwin did envisage humans as a part of the natural order of things and in defining the human species as a "modified descendant of some pre-existing form," Darwin (1874: 5) showed the common descent of humans and animals, concluding from the continuity between the human and the animal sphere that their distinction is only a difference in degree and not in kind, thus including humanity into the animal sphere. As Darwin (1874: 147) puts it himself: "A difference in degree, however great, does not justify us in placing man in a distinct kingdom." One effect of this Darwinian shift in the understanding of the relationship between human beings and animals was the breakthrough of a strictly naturalistic view of human nature. Since humanity was regarded as part of nature, not above it, and therefore subject to its laws, the methods of the natural sciences seemed to be applicable in anthropology. Hutton (2005: 48-51) has emphasized that modern eugenics was a direct application of this vision. He also shows that, from a Darwinian perspective, the cultural development of humanity was regarded as peculiar case of domestication, analogues to the human breeding of animals and plants. 
These animalizing tendencies were especially obvious in the Darwinian reformulation of racial anthropology. In the methodological chapter of the Baur-Fischer-Lenz volume, Lenz emphasized the scientific status of racial anthropology and singled out two objective sources of knowledge about the natural development of humanity: statistical methods and analogies from the experience of breeding animals and plants (Lenz 1927a: 411-416). ${ }^{\mathrm{ix}}$ Moreover, races were considered as the key agents of human life and analogies with the animal world loomed large in the explanation of their genetic make-up. Baur (1927) explained the selective mechanism that regulated the mixture of different racial groups by the comparison with the interbreeding of a population of white rabbits with a population of black rabbits. He also pointed to the similarities between the domestication of animals and the cultivation of humans, emphasizing and criticizing, however, the missing selection in human culture (Baur 1927: 74-81; see also Fischer 1927: 136 f.). From this biologistic perspective, cultural development was nothing but the expression of a community's natural development regarding its intellectual capacities. For Baur, Fischer, and Lenz natural dispositions determined the cultural capacity of races, and caused their alleged developmental differences. Lenz (1927b) outlined a typical cultural hierarchy of races, starting with the supposed lowest stage of "primitive prehistoric races" who lacked the intellectual capacity for developing culture and, therefore, lived like primates. He believed that members of these ape-like humans still existed (i.e. in Australia) and claimed that the gap between them and the intellectually most gifted humans was as large as the gap between humans and primates in general. Moreover, the "negro race" was depicted as "inferior" within the spectrum of historic humanity, lacking the intellectual capacity for creativity, living only for the moment and in unorganized tribes, prone to child-like self-indulgence and cruelty (Lenz 
1927b: 523-25, 529; for Fischer's similar views see Hutton 2005). The Nordic race represented, of course, the peak of the intellectual development of humanity, bearing its cultural advancement. Gifted with creative intelligence and the capacity to develop strong personalities, members of the Nordic race were determined to become leaders, conquerors, inventors, artists, scientists, and thinkers. Lenz claimed, however, that these characteristics grounded the Nordic inclination to individualism.

At this point the significance of animalizing motifs for biological anthropology after Darwin should be obvious: Since humanity was regarded as part of nature, its characteristics were explained by the same laws that governed the animal world. These naturalistic explanations were often based on analogies between animal and human life, emphasizing the similarities between them. The racial anthropology of Baur, Fischer, and Lenz assumed that there were large evolutionary gaps within humanity and advanced a hierarchy of races that moved certain groups of people closer to animals than others (for the modern prehistory of these motifs see Sebastiani, this volume). They thus promoted a separation within humanity itself and even contributed to the myth of the Nordic race with their scientific claims, making them scientific allies of Nazi ideology.

b) Philosophical Anthropology: The establishment of a Darwinian anthropology, which was advocated successfully by authors like Ernst Haeckel, faced strong opposition in Germany, especially in philosophy. Most philosophers regarded a naturalistic view in anthropology as theoretically insufficient and ethically dangerous. They raised the ethical concern of 
dehumanization, accusing naturalistic approaches of animalizing humanity and of disregarding the normative aspect of human life. Biological anthropology was identified with a kind of human zoology that stripped off meaning and dignity of humanity, thus contributing to the crisis of modern life by undermining traditional forms of human self-understanding. ${ }^{x}$ Philosophers developed their anthropological approaches against the perceived threat of its decline into animality and sought to reconstruct the special status of humanity by revealing what is uniquely human. This essence of being human was thought to transcend the realm of nature. In his summary of contemporary philosophical anthropology in 1938, Werner Sombart characterized this anti-naturalistic stance as the common orientation of the different approaches (Sombart 1938: 126; for a confirmation of this tendency see Hutton 2005: $253 \mathrm{ff}$.$) .$

Max Scheler was a key protagonist of the general tendency in anthropological thought in German philosophy. He began his treatise Die Stellung des Menschen im Kosmos (1928; The Human Place in the Cosmos) with diagnosing an anthropological identity crisis, claiming that despite the increase of empirical knowledge about humanity "in no historical era has the human being become so much of a problem to himself as in ours" (Scheler 2009: 5). His critical diagnosis was explicitly directed against the empirical sciences and pointed to the ethical deficiency of their naturalistic understanding of humanity: Although humanity knew more about its place in the natural world than ever before, it had become more uncertain about its distinctive nature and destiny. 
Scheler regarded the anthropological identity crisis as an opportunity to reveal the true nature of humanity and thus addressed a "tricky ambiguity" of the concept human being (Scheler 2009: 5). He distinguished two senses of the concept human being and defined them as fundamentally different. On the one hand, Scheler held that the term human being was used in the natural sciences, characterizing humans as a subclass of vertebrates and mammals, and thus including them in the animal sphere. On the other hand, Scheler claimed that there was an "essential concept" (Wesenskonzept) of the human which completely opposed the naturalistic understanding and, moreover, the concepts of animals in general (Scheler 2009:5). He was convinced that humans were not only natural beings, but characterized by the capacity to transcend nature. In an earlier article on Zur Idee des Menschen (1915; On the Idea of Man) Scheler defined humans as "God-seekers," arguing that this orientation to transcendence made them truly human (Scheler 1978: 194). In the later treatise, he understood this fundamental condition of being human as spirit. According to the late Scheler, humans embodied spirit and their life was thus shaped by a metaphysical principle that was in opposition to natural life. The spiritual principle of human life made humans independent from nature and enabled them to develop self-consciousness. Scheler argued that this fundamental distinction from the animal sphere constituted the special status and, hence, the true nature of humanity.

Note that Scheler believed that his differentiation between a natural and an essential sense of being human revealed a distinction that could be found in reality. In his article from 1915, Scheler claimed that "there is within 'humanity' a separation, which is immensely larger than the naturalistic one between man and animal" (Scheler 1978: 194). He suggested that there 
were beings who were only human from a naturalistic perspective and that these natural humans were not fully human because they did not fulfil the essential concept of being human. Scheler emphasized that they were fundamentally different from human beings in the essential sense and only gradually different from other animals, thus characterizing them as human animals. I believe it is fair to say that Scheler developed an anthropological framework that could be used to dehumanize certain groups of people, although he did not develop such a racist line of thought and was not affiliated with Nazi ideology. Philosophers who connected their views with NS relied nevertheless on Scheler's anthropological thought, advancing a political understanding of his key motifs that was compatible with Nazi ideology. ${ }^{\mathrm{x}}$

To sum up, my outline of the two competing main strands of anthropology in early-twentiethcentury Germany demonstrates that the key motifs of Nazi anthropology were well embedded in the broader historical context. Both examples show that the concepts of humanity that grounded the dehumanizing strategies of Nazi ideology were prevalent in the scholarly debates of the time. The case of NS thus exemplifies the dehumanizing potential of anthropological theories.

\section{Conclusion}

The analysis above explores the significance of dehumanizing images for Nazi ideology, focusing on the connection between concepts of humanity and strategies of dehumanization. Yet dehumanization was not only an ideological phenomenon in the context of NS. Dehumanizing 
practices shaped the social reality of NS (for examples see Brudholm and Lang, this volume). ${ }^{\text {ii }}$ Several authors have claimed that the notion of a complete dehumanization, which is often advanced by psychological approaches (e.g. Kelman 1973; Smith 2011, 2016, this volume), is not sufficiently supported by the actual reality of mass violence. Lang's (2010) detailed account of the excessive violence in concentrations camps demonstrates that the perpetrators did not transform their victims in completely non-human beings (see also Lang 2017; Brudholm 2010). He shows that the extreme forms of violence that characterized the daily life in concentration camps had a social psychological meaning that implied the acknowledgement of the victim's humanity. Lang argues that this intersubjective dimension of the violent behavior of perpetrators cannot be captured by the concept of dehumanization, since the completely dehumanized other is per definition deprived of any social meaning for the dehumanizer. My examination of different versions of Nazi ideology has, however, unearthed complex strategies of dehumanization that allowed the attribution of basic human traits to the victims of dehumanization. The image of the human animal was characterized by an irreducible ambivalence and does not lead to a complete dehumanization of the other. My understanding of dehumanization is thus consistent with the fact that perpetrators recognized some kind of humanity in their victims. I also do not have to make an additional theoretical assumption such as an incoherent state of mind that should be specific to the psychology of dehumanization (Smith, this volume).

I believe that considering the social context of dehumanization suggests a broader shift in examining this troubling phenomenon. In the existing literature, processes of dehumanization 
are, first and foremost, discussed as psychological prerequisites of mass violence. This debate focuses on the psychology of perpetrators and attempts to determine the causal role of dehumanization for participating in acts of mass violence. Yet the social perspective highlights the practical aspect of dehumanization. In guiding the interaction with other people, dehumanization proves to be a forceful tool of social oppression that has a strong psychological impact on its victims. Future research on dehumanization in contexts of mass violence should thus consider the perspective of the victims more thoroughly and examine the constitutive role of dehumanization in their treatment (see Demoulin et al, this volume). This focus could connect the research on dehumanization in contexts of mass violence with other research strands, since the role of dehumanization as the normative wrong of social harm is discussed in fields such as feminist philosophy (e.g. Mikkola 2016) or philosophy of law (e.g. Frick, this volume; Corrias, this volume).

\section{Acknowledgments}

For critical comments and helpful suggestions on an earlier draft of this paper, I want to thank Maria Kronfeldner and two anonymous referees.

\section{Literature}

Bärsch, C.E. (2002) Die politische Religion des Nationalsozialismus. Die religiöse Dimension der NS-Ideologie in den Schriften von Dietrich Eckart, Joseph Goebbels, Alfred Rosenberg und Adolf Hitler, München: Wilhelm Fink. 
Baur, E. (1927), “Abriß der allgemeinen Variations- und Erblichkeitslehre”, in E. Baur, E. Fischer and F. Lenz, Menschliche Erblichkeitslehre, München: Lehmann, 1-82

Brudholm, Th. (2010) “Hatred as an Attitude," Philosophical Papers 39:289-313.

Confino, A. (2014) A World Without Jews: The Nazi Imagination from Persecution to Genocide, New Haven and London: Yale University Press.

Darré, R.W. (1937 [1930]) Neuadel aus Blut und Boden, München: Lehmann.

-----(1940a) “Der Lebensbaum unserer Altvordern im Lichte neuzeitlicher Naturwissenschaft," in Erkenntnisse und Werden. Aufsätze aus der Zeit vor der Machtergreifung, Goslar: Blut und Boden.

-----(1940b) “Auseinandersetzung mit Böhmers Werk 'Das Erbe der Enterbten,'” Erkenntnisse und Werden. Aufsätze aus der Zeit vor der Machtergreifung, Goslar: Blut und Boden.

-----(1942 [1929]) Das Bauerntum als Lebensquell der Nordischen Rasse, München: Lehmann.

Darwin, Ch. (1875) The Descent of Man and Selection in Relation to Sex, New York: D. Appleton.

Fischer, E. (1927), "Die Rassenunterschiede des Menschen,” in E. Baur, E. Fischer and F. Lenz, Menschliche Erblichkeitslehre, München: Lehmann, 83-168.

Fiske, A., T. Rai (2014) Virtuous Violence: Hurting and Killing to Create, Sustain, End, and Honor Social Relationships, Cambridge: Cambridge University Press.

Gauch, H. (1933) Neue Grundlagen der Rassenforschung, Leipzig: Adolf Klein.

Gies, H. (2019) Richard Walther Darré: Der "Reichsbauernführer", die nationalsozialistische "Blut und Boden"-Ideologie und Hitlers Machteroberung, Köln: Böhlau. 
Harrington, H. (1996), Reenchanted Science. Holism in German Culture from Wilhelm II to Hitler, Princeton: Princeton University Press.

Hitler, A. (1925) Mein Kampf. Erster Band: Eine Abrechnung, München: Franz Eher. Hutton, C.M. (2005) Race and the Third Reich: Linguistics, Racial Anthropology and Genetics in the Dialectic of Volk, Cambridge: Polity.

Kelman, H.C. (1973) "Violence without Moral Restraint: Reflections on the Dehumanization of Victims and Victimizers," Journal of Social Issues 29:25-61.

Koonz, C. (2003) The Nazi Conscience, Cambridge, Mass.: Harvard University Press.

Kroll, F.L. (1998) Utopie als Ideologie. Geschichtsdenken und politisches Handeln im Dritten Reich, Paderborn: Ferdinand Schöningh.

Kuper, L. (1981) Genocide: Its Political Use in the Twentieth Century, New Haven: Yale University Press.

Lang, J. (2010) “Questioning Dehumanization: Intersubjective Dimensions of Violence in the Nazi Concentration and Death Camps," Holocaust and Genocide Studies 24:225-246.

-----(2017)“Explaining Genocide: Hannah Arendt and the Social-scientific Concept of

Dehumanization," in P. Baehr and P. Walsh (eds.) The Anthem Companion to Hannah Arendt, London: Anthem Press.

Lenz, F. (1927a), “Die Methoden menschlicher Erblichkeitsforschung,", in E. Baur, E. Fischer and F. Lenz, Menschliche Erblichkeitslehre, München: Lehmann, 409-468

---- (1927b), “Die Erblichkeit der geistigen Begabung,” in E. Baur, E. Fischer and F. Lenz, Menschliche Erblichkeitslehre, München: Lehmann, 469-583 
Lersch, P. (1936) “Grundsätzliches zur Lebensphilosophie," Blätter für Deutsche Philosophie 10:22-55.

Mikkola, M. (2016) The Wrong of Injustice. Dehumanization and its Role in Feminist Philosophy, Oxford: Oxford University Press.

Raphael, L. (2014) “Pluralities of National Socialist Ideology: New Perspectives on the Production and Diffusion of National Socialist Weltanschauung," in M. Steber and B. Gotto (eds.) Visions of Community in Nazi Germany: Social Engineering and Private Lives, Oxford: Oxford University Press.

Rosenberg, A. (1938 [1930]) Der Mythus des 20. Jahrhunderts. Eine Wertung der seelischgeistigen Gestaltenkämpfe unserer Zeit, München: Hoheneichen-Verlag.

-----(1971) Race and Race History and Other Essays by Alfred Rosenberg, trans. R. Pois, London: Jonathan Cape.

Rothacker, E. (1934) Geschichtsphilosophie, Bonn: München and Berlin: Oldenburg.

Scheler, M. (1978 [1915]) "On the Idea of Man", trans. C. Nabe, Journal of the British Society for Phenomenology 9:1984-198.

-----(2009 [1928]), The Human Place in the Kosmos, trans. M. S. Frings, Evanston: North Western University Press.

Sluga, H. (1993) Heidegger's Crisis: Philosophy and Politics in Nazi Germany, Cambridge, Mass.: Harvard University Press. 
Smith, D.L. (2011) Less Than Human: Why We Demean Enslave, and Exterminate Others, New York: St. Martin's Press.

-----(2016) “Paradoxes of Dehumanization," Social Theory and Practice 42:416-443.

Sombart, W. (1938) "Beiträge zur Geschichte der wissenschaftlichen Anthropologie," in

Sitzungsberichte der Preußischen Akademie der Wissenschaften, Philosophisch-

historische Klasse, Berlin: Verlag der Akademie der Wissenschaften, 96-130.

Steizinger J. (2018) “The Significance of Dehumanization: Nazi Ideology and its Psychological Consequences," Politics, Religion \& Ideology 19:139-157.

-----(2020) “From Völkerpsychologie to Cultural Anthropology: Erich Rothacker's Philosophy of Culture," HOPOS 10, in press.

Varshizky, A. (2017a) “In Search of the 'Whole Man': Soul-Man-World in the National Socialist Weltanschauung," Dapim: Studies on the Holocaust 31:200-226.

-----(2017b) “Between science and metaphysics: Fritz Lenz and racial anthropology in interwar Germany," Intellectual History Review 27:247-272.

Volpato, C., A. Contarello (1999) “Towards a social psychology of extreme situations: Primo Levi's If This is a Man and social identity theory," European Journal of Social Psychology 29:5587.

Weingart, P., K. Bayertz, J. Kroll (1992) Rasse, Blut und Gene. Geschichte der Eugenik und Rassenhygiene in Deutschland, Frankfurt/.M: Suhrkamp. 
Weikart, R. (2004) From Darwin to Hitler: Evolutionary Ethics, Eugenics, and Racism in Germany, New York: Palgrave Macmillan.

Weiss, S. (2010) The Nazi Symbiosis: Human Genetics and Politics in the Third Reich, Chicago: University of Chicago Press.

Weißmann, M. (2015) “Organisierte Entmenschlichung. Zur Produktion, Funktion und Ersetzbarkeit sozialer und psychischer Dehumanisierung in Genoziden, "in A. Gruber and S. Kühl (eds.) Soziologische Analysen des Holocaust. Jenseits der Debatte über „ganz normale Männer" und "ganz normale Deutsche", Wiesbaden: Springer VS.

\footnotetext{
' Nazi ideologues regarded their racist views as contributions to the (self-)understanding of humanity. Since their approaches were well embedded in the scholarly debates of the time (as I will argue in this chapter), they belong to the anthropological discourse of the early twentieth century. In identifying the views of Nazi ideologues as anthropologies, my wording should reflect this historical context.

ii I abstain from discussing the relationship between dehumanization and the emergence of mass violence. For a careful analysis of the role of ideological dehumanization for the motivation of Nazi perpetrators see Steizinger 2018.

iii I will quote Rosenberg's main work Der Mythus des 20. Jahrhunderts (The Myth of the 20th Century) from the translated selections printed in: Race and Race History and Other Essays by Alfred Rosenberg. If I quote Rosenberg in English, I will always provide a reference to the
} 
German original in brackets. It is always noted, when I translate a passage from the German edition myself.

iv For a more detailed examination of Rosenberg's doctrine that considers the recent literature see my previously published account in Steizinger 2018.

${ }^{\vee}$ This motif is most developed in Rosenberg's early work Die Spur des Juden im Wandel der Zeit (1920). Passages from this anti-Semitic treatise are published in Rosenberg 1971, 175-190.

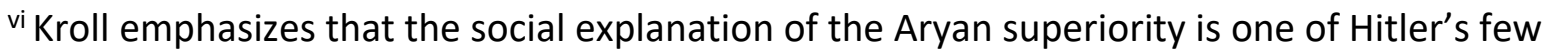
original contributions to the racist discourse. See Kroll 1998, $47 \mathrm{f}$.

vii Hutton (2005) gives a detailed account of the struggles between the different racial paradigms within the Nazi context.

viii The Baur-Fischer-Lenz volume was first published in 1921 and became the standard work on racial anthropology in the 1920s and 1930s.

ix I concentrate on Lenz' claims in the Baur-Fischer-Lenz volume. Here, Lenz advanced a strictly naturalistic position without the metaphysical overtones that Varshizky (2017b) finds in other works. A discussion of the development of Lenz' views and of his understanding of the relationship between science and ideology would extend the scope of this paper.

x Milam (this volume) shows that structurally similar oppositions characterized anthropological debates in postwar America.

xi See, e.g. Rothacker 1934; Lersch 1936. For a detailed analysis of racist underpinnings of Rothacker's philosophical anthropology see Steizinger 2020.

xii The close relationship between Nazi ideology and Nazi reality from the perspective of dehumanization is set out by Steizinger 2018. 